\title{
"Soil biofilms": Misleading description of the spatial distribution of microbial biomass in soils
}

\author{
Philippe C. Baveye ${ }^{1,2}$ \\ 1 UMR Ecosys AgroParisTech, Université Paris-Saclay, avenue Lucien Brétignières, 78850 Thiverval-Grignon, France \\ 2 Saint Loup Research Institute, 7 rue des chênes, La Grande Romelière, 79600 Saint Loup Lamairé, France \\ (c) Higher Education Press 2020
}

In a recent article in this journal, Cai et al. (2019) argue that, until now, "the importance of soil biofilms has largely been ignored", and that this oversight needs to be corrected because, from their perspective, biofilms are a "dominant growth form", central to many processes occurring in soils. These authors make a fervent plea that research take place in different fields "to lay the foundation for researching soil biofilms and to drive this field into a new era." This assessment and the suggestions that ensue raise a number of fundamental questions, however, in particular because they stem from bypassing a significant body of literature on the spatial distribution of soil microorganisms.

Some of the background of these assertions is without contest. There is no doubt that, in the literature dealing with soils, biofilms have occupied a very modest place, in sharp contrast with what has occurred in many other disciplines over the last 4 decades. Indeed, be it in water distribution systems, on teeth or in the gut of animals, or on solid surfaces immersed in rivers, lakes, or oceans, i.e., whenever a surface is in contact with water for extended lengths of times, countless researchers (e.g., Block, 1992; Block et al., 1993; Boltz et al., 2017; Flemming and Wuertz, 2019) have shown the presence of biofilms, defined as bacterial (or archeal) cells in a selfproduced matrix of hydrated extracellular polymeric substances (EPS), through which in most cases nutrients and metabolites are hypothesized to be transported solely via diffusion. Similarly, biofilms have been evinced to occur at water-solid, water-air, and NAPL-water interfaces. Given their apparent ubiquity in natural and man-made situations, it is hardly surprising that biofilms have been the object of an enormous literature, and that many aspects of their function, structure, and dynamics have been thoroughly studied and

Received December 19, 2019; revised January 30, 2020; accepted February 9, 2020

E-mail address: philippe.baveye@AgroParisTech.fr (P.C. Baveye) modelled mathematically.

Some of the perspectives on biofilms have evolved over time. Forty years ago, biofilms were thought to cover surfaces or interfaces uniformly, hence the term of "film." However, it has since become obvious that in many instances, for a variety of reasons (e.g., hydrodynamics, predation), biofilms are more likely to be patchy than to cover surfaces or interfaces entirely, with no consensus existing at the moment on a minimum size necessary for a group of cells and their surrounding EPS to be labelled as a biofilm (Flemming and Wuertz, 2019). In a number of fora, in particular at meetings of the so-called "Biofilms club", there have been over the years many heated discussions about the adequacy to keep the term of biofilm, in the absence of a "film" of any kind (Hans-Curt Flemming, personal communication, December 2019).

In this general context, given the amount of research devoted to biofilms, it may seem surprising at first that it has been only recently that a few scientists working on soils have mentioned biofilms in their work (e.g., Redmile-Gordon et al., 2014; Castorena et al., 2016; Volk et al., 2016; Coyte et al., 2017; Lerch et al., 2017; Aufrecht et al., 2019), and have therefore availed themselves of all the conceptual and modelling tools that have been developed to describe biofilms in other environments. One might think that there should be little difference practically between a pebble in a riverbed, a sand particle in a water-saturated sandy soil, or the simulated sand-like particle in a microfluidics device, and that one should therefore find biofilms in all of these systems. However, the fact that in the latter two cases one is dealing with a porous medium drastically slows down the bulk movement of the liquid phase, thereby altering substantially the hydrodynamic and nutritional conditions encountered by microorganisms. Even under conditions where it would seem most likely to find biofilms in any porous medium, i.e., when bioclogging occurs, that is not at all what happens. Experimental results on the bioclogging of water-saturated sand columns by bacteria show that the 
concept of biofilm, covering the surfaces either uniformly or patchily, does not correspond at all to the reality that is observed. Heterogeneous groups of bacteria, restricting the flow at pore constrictions in several ways (e.g., via accumulation of cells, production of exopolymers, or insoluble gas release), are causing the observed clogging (e.g., Vandevivere and Baveye, 1992a). In cases of bioclogging via the accumulation of cells and associated polymers, the use of advanced sample preparation techniques prior to scanning electron microscopy (Vandevivere and Baveye, 1992b, 1992c) made it possible to demonstrate that bacterial cells are neither entirely "planktonic" nor adsorbed onto solid surfaces but extend away from the surfaces into the lumen of pores, as illustrated particularly clearly in Figure $3 \mathrm{~b}$ of Vandevivere and Baveye (1992a). In parallel, modelling efforts attempting to describe the clogging process in sands on the basis of traditional diffusion-limited biofilms have overwhelmingly failed (Vandevivere and Baveye, 1995; Thullner and Baveye, 2008).

In actual soils, there are not just sand particles but also much smaller ones, including clay or oxide minerals as well as organic matter, and therefore on average, the dimensions of the pore space accessible to microorganisms are far smaller than in sands. The case against biofilms in these situations is even more clear cut. Aside from the excessive reliance of soil microbiologists in recent years on metagenomics techniques, which do not require any knowledge of the spatial configuration of soil biomass, a key reason very few people have been talking about soil biofilms in these systems, is simply because experimental evidence that biofilms exist in real soils is virtually non-existent. Starting in the $50 \mathrm{~s}$, and especially after the advent of transmission or scanning electron microscopes, as well as, later, of laser scanning microscopes, various soil scientists have accumulated a wealth of visual information about the spatial distribution of bacteria and archaea in soils (e.g., Clark, 1951; Jones and Griffiths, 1964; White et al., 1994; DeLeo et al., 1997; Nunan et al., 2001; Li et al., 2003, 2004; Eickhorst and Tipköttter, 2008; Raynaud and Nunan, 2014; Watteau et al., 2018; Juyal et al., 2019), including at the interfaces between soil and plant roots (e.g., Danhorn and Fuqua, 2007; Cardinale, 2014; Schmidt et al., 2018). None of the micrographs that were produced with these tools show anything that even vaguely looks like a film, patchy or not. The comprehensive, landmark review by Foster (1988) is particularly clear in this respect. At best, what one finds is very small, isolated groups of cells, sometimes coated with clay particles, and embedded in partially-degraded organic matter or surrounded by EPS. The vision these images convey, of microbial life in soils not being a particularly social existence, is entirely supported by estimates of spatial densities of microbial cells in soils, calculated by various authors over the years (e.g., Postma and van Veen, 1990; Grundmann, 2004; Young and Crawford, 2004; O'Donnell et al., 2007; Vos et al., 2013; Kuzyakov and Blagodatskaya, 2015; Baveye et al., 2018).

Based on this wealth of information, it seems questionable at best to try to promote the use of the concept of "soil biofilm", as Cai et al. (2019) do. Since the heterogeneous groups of microbial cells that are present in soils do not look at all like films tightly or even loosely adsorbed onto solid surfaces or located at interfaces, it seems that very little would be gained by labelling them as such. Why call something a "film" if it is not a film at all? Why, practically speaking, promote the use of the expression "soil biofilm" in a discipline where there is no tradition of doing so, and no real benefit to be derived from it? Beyond a mere semantic issue, the use of the biofilm terminology may encourage some authors to use in a soil context the various tools (e.g., computer models) developed to describe actual biofilms. This approach, if the example of bioclogging can serve as a guide, is unlikely to be a recipe for success.

This conclusion then begs the question of what terminology, if any, to adopt when describing the spatial distribution of soil bacteria or archaea. Some authors (e.g., Nunan, 2017) have proposed to refer to groups of cells in soils as "soil microbial aggregates" or "micro-aggregates." Wilpiszesk et al. (2018) use the expression "soil aggregate microbial communities" instead. All three of these suggestions unfortunately have a very high potential to lead to utter confusion, since the term of aggregate has until recently been widely used in a portion of the soil literature to describe an entirely distinct type of structure (e.g., Kravchenko et al., 2019). Other authors (e.g., Foster, 1988; Or et al., 2007) have opted instead to use the term of "colony", which is not affected by the same type of ambiguity, but makes it tempting to assume, as, e.g., Molz et al (1986) did, that there is some regularity in the size of the colonies, which is generally not the case. An alternative approach, advocated by Baveye and Valocchi (1989), is to avoid altogether getting hooked on terms like biofilm or (micro) colony, which may suggest the existence of some kind of pattern in the spatial distribution of microorganisms in soils, when the reality is utterly heteroclitic. We could simply refer to "groups of cells occupying specific microenvironments", without ever trying to be more precise about the size or shape of these "groups". The advantage of this perspective is that it associates in the same expression the groups of cells and their immediate surroundings, whose physical-chemical characteristics undoubtedly influence the behaviour of cells and therefore must be taken into account explicitly in any attempt to describe microbial activity in soils (Baveye et al., 2018). By not assuming more about the spatial distribution of microorganisms than what we know, I feel that we would not only be far more consistent with the findings of a significant body of literature that should not be bypassed, but we would also approach the research from a much sounder conceptual vantage point.

\section{References}

Aufrecht, J.A., Fowlkes, J.D., Bible, A.N., Morrell-Falvey, J., Doktycz, M.J., Retterer, S.T., 2019. Pore-scale hydrodynamics influence the spatial evolution of bacterial biofilms in a microfluidic porous 
network. PLoS One 14(6): e0218316.

Baveye, P.C., Otten, W., Kravchenko, A., Balseiro Romero, M., Beckers, É, Chalhoub, M., Christophe, D., Thilo, E., Patricia, G., Simona, H., Serkan, K., Olivier, M., Carsten, W.M., Naoise, N., Valérie, P., Steffen, S., Hannes, S., Hans-Jörg, Vogel., 2018. Emergent properties of microbial activity in heterogeneous soil microenvironments: different research approaches are slowly converging, yet major challenges remain. Frontiers in Microbiology 8, 1364.

Baveye, P., Valocchi, A., 1989. An evaluation of mathematical models of the transport of biologically reacting solutes in saturated soils and aquifers. Water Resources Research 25, 1413-1421.

Block, J.C., 1992. Biofilms in Drinking Water Distribution Systems. In: Melo, L.F., Bott, T.R., Fletcher, M., Capdeville, B. (eds.) Biofilms Science and Technology. NATO ASI Series (Series E: Applied Sciences), vol 223. Springer, Dordrecht

Block, J.C., Haudidier, K., Paquin, J.L., Miazga, J., Levi, Y., 1993, Biofilm accumulation in drinking water distribution systems, Biofouling 6, 333-343,

Boltz, J.P., Smets, B.F., Rittmann, B.E., van Loosdrecht, M.C.M., Morgenroth, E., Daigger, G.T., 2017. From biofilm ecology to reactors: a focused review. Water Science and Technology 75, 1753-1760.

Cai, P., Sun, X., Wu, Y., Gao, C., Mortimer, M., Holden, P.A., RedmileGordon, M., Huang, Q., 2019. Soil biofilms: microbial interactions, challenges, and advanced techniques for ex-situ characterization. Soil Ecology Letters 1(3-4), 85-93.

Cardinale, M., 2014. Scanning a microhabitat: plant-microbe interactions revealed by confocal laser scanning microscopy. Frontiers in Microbiology 5, 94.

Castorena, E.V.G., Gutierrez-Castorena, M.C., Vargas, T.G., Bontemps, L.C., Delgadillo Martinez, J., Suastegui Mendez, E., Solorio, C.A.O. 2016. Micromapping of microbial hotspots and biofilms from different crops using digital image mosaics of soil thin sections. Geoderma 279, 11-21.

Clark, F.E., 1951. Bacteria in the soil. Experientia 7, 78-80.

Coyte, K.Z., Tabuteau, H., Gaffney, E.A., Foster, K.R., Durham, W.M., 2017. Biofilm competition in porous environments. Proceedings of the National Academy of Sciences 114, E161-E170;

Danhorn, T., Fuqua, C., 2007. Biofilm formation by plant-associated bacteria. Annual Review of Microbiology 61, 401-422.

DeLeo, P.C., Baveye, P., Ghiorse, W.C., 1997. Use of confocal laser scanning microscopy on soil thin-sections for improved characterization of microbial growth in unconsolidated soils and aquifer materials. Journal of Microbiological Methods 30, 193-203.

Eickhorst, T., Tippkötte, R., 2008. Detection of microorganisms in undisturbed soil by combining fluorescence in situ hybridization (FISH) and micropedological methods. Soil Biology Biochemistry 40, 1284-1293.

Flemming, H.C., Wuertz, S., 2019. Bacteria and archaea on earth and their abundance in biofilms. Nature Reviews Microbiology 17, $247-$ 260.

Foster, R.C., 1988. Microenvironments of soil microorganisms. Biology and Fertility of Soils 6, 189-203.

Foster, R.C., Rovira, A.D., Cock, T.W., 1983. Ultrastructure of the RootSoil Interface. St Paul, MN: American Phytophathological Society.
Grundmann, G.L., 2004. Spatial scales of soil bacterial diversity - The size of a clone. FEMS Microbiology Ecology 48, 119-127.

Jones, D., Griffiths, E., 1964. The use of thin soil sections for the study of soil microorganisms. Plant Soil 20, 232-240.

Juyal A., Otten W., Falconer R., Hapca S., Schmidt H., Baveye P.C., Eickhorst T., 2019. Combination of techniques to quantify the distribution of bacteria in their soil microhabitats at different spatial scales. Geoderma 334, 165-174.

Kravchenko, A.N., Otten, W., Garnier, P., Pot, V. and Baveye, P.C., 2019. Soil aggregates as biogeochemical reactors: Not a way forward in the research on soil-atmosphere exchange of greenhouse gases. Global Change Biology 25, 2205-2208.

Kuzyakov, Y., Blagodatskaya, E., 2015. Microbial hotspots and hot moments in soil: concept and review. Soil Biology Biochemistry 83, 184-199.

Lerch, T.Z., Chenu, C., Dignac M.F., Barriuso, E., Mariotti, A., 2017. Biofilm vs. planktonic lifestyle: consequences for pesticide 2,4-D metabolism by Cupriavidus necator JMP134. Frontiers in Microbiology 8, 904.

Li, Y., Dick, W.A., Tuovinen, O.H., 2003. Evaluation of fluorochromes for imaging bacteria in soil. Soil Biology Biochemistry 35, 737744.

Li, Y., Dick, W.A., Tuovinen, O.H., 2004. Fluorescence microscopy for visualization of soil microorganisms - A review. Biology and Fertility of Soils 39, 301-311.

Molz, F.J., Widdowson, M.A., Benefield, L.D., 1986. Simulation of microbial growth dynamics coupled to nutrient and oxygen transport in porous media, Water Resources Research 22, 1207 1216.

Nunan, N., 2017. The microbial habitat in soil: scale, heterogeneity and functional consequences. Journal of Plant Nutrition and Soil Science 180, 425-429.

Nunan, N., Ritz, K., Crabb, D., Harris, K., Wu, K., Crawford, J.W., Young, I.M., 2001. Quantification of the in situ distribution of soil bacteria by large scale imaging of thin sections of undisturbed soil. FEMS Microbiology Ecology 37, 67-77.

O'Donnell, A.G., Young, I.M., Rushton, S.P., Shirley, M.D., Crawford, J. W., 2007. Visualization, modelling and prediction in soil microbiology. Nature Reviews Microbiology 5, 689-699.

Or, D., Smets, B.F., Wraith, J.M., Dechesne, A., Friedman, S.P., 2007. Physical constraints affecting bacterial habitats and activity in unsaturated porous media - a review, Advances in Water Resources 30, 1505-1527.

Pennell, K.D. (2016). "Specific surface area," in Elias, S.A. (ed.) Reference Module in Earth Systems and Environmental Sciences, Oxford: Elsevier, 1-8.

Postma, J., van Veen, J.A., 1990. Habitable pore space and survival of Rhizobium leguminosarum biovartrifolii introduced into soil. Microbial Ecology 19, 149-161.

Redmile-Gordon, M.A., Brookes, P.C., Evershed, R.P., Goulding, K.W. T., Hirsch, P.R., 2014. Measuring the soil-microbial interface: Extraction of extracellular polymeric substances (EPS) from soil biofilms, Soil Biology and Biochemistry 72, 163-171.

Raynaud, X., Nunan, N., 2014. Spatial ecology of bacteria at the microscale in soil. PLoS One 9, 287217.

Thullner, M., Baveye, P., 2008. Computational pore network modeling 
of the influence of biofilm permeability on bioclogging in porous media. Biotechnology \& Bioengineering 99, 1337-1351.

Vandevivere P., Baveye P., 1992a. Saturated hydraulic conductivity reduction caused by aerobic bacteria in sand columns. Soil Science Society of America Journal 56,1-13

Vandevivere, P., Baveye, P., 1992b. Improved preservation of bacterial exoplolymers for scanning elecrton microscopy. Journal of Microscopy-Oxford 167, 323-330.

Vandevivere, P., Baveye, P., 1992c. Sampling method for the observation of microorganisms in unconsolidated porous media via scanning electron microscopy. Soil Science 153, 482-485.

Vandevivere, P., Baveye, P., de Lozada, D.S., DeLeo, P., 1995. Microbial clogging of saturated soils and aquifer materials: Evaluation of mathematical models. Water Resources Research 31, 2173-2180.

Volk, E., Iden, S.C., Furman, A., Durner, W., Rosenzweig, R., 2016. Biofilm effect on soil hydraulic properties: Experimental investigation using soil-grown real biofilm, Water Resources Research 52,
5813-5828.

Vos, M., Wolf, A.B., Jennings, S.J., Kowalchuk, G.A., 2013. Microscale determinants of bacterial diversity in soil. FEMS Microbiology Reviews 37, 936-954.

Watteau, F., Villemin, G., 2018. Soil microstructures examined through transmission Electron microscopy reveal soil-microorganisms interactions. Frontiers in Environmental Science 6, 106.

White, D., FitzPatrick, E.A., Kilham, K., 1994. Use of stained bacterial inocula to assess spatial distribution after introduction into soil. Geoderma 63, 245-254.

Wilpiszeski, R.L., Aufrecht, J.A., Retterer, S.T., Sullivan, M.B., Graham, D.E., Pierce, M., Zablocki, E., Palumbo, A.V., Elias, D.A., 2019. Soil aggregate microbial communities: towards understanding microbiome interactions at biologically relevant scales. Applied and Environmental Microbiology 85, e00324-19.

Young, I.M., Crawford, J.W., 2004. Interactions and self-organization in the soil-microbe complex. Science 304, 1634-1637. 